\title{
Menjerat Kader, Melepas Partai Politik; Pertanggungjawaban Pidana Partai Politik Dalam Kasus Tindak Pidana Korupsi
}

\author{
Zulkifli Aspan \\ Fakultas Hukum Universitas Hasanuddin, Makassar, Indonesia \\ E-mail : zulkifliaspan@gmail.com \\ Wiwin Suwandi \\ Peneliti Anti Coruption Committee (ACC) Sulawesi, Indonesia \\ E-mail : wiwin.lawyer@gmail.com
}

\begin{abstract}
Amid the resounding steps of the KPK to carry out the law enforcement function of eradicating Corruption, there are still things that feel stagnant. The KPK does not or has not dared to ensnare political parties in corrupt criminal liability, using corruption laws. In each case with dimensions of political corruption, the KPK only ensnares party elites, but does not at the same time demand criminal liability from political parties. In fact, in several cases investigated, the flow of funds flowed into political parties. As a special offense, revising the Corruption Law, by entering the phrase "legal entity", in addition to the phrase "everyone" is needed to find, or build a channel to ensnare political parties in corruption criminal liability. accompanied by state losses and fines. Administrative sanctions can also be applied through freezing through the Kemenkumham or the dissolution of these political parties through the Constitutional Court's path when the KPK's charges and demands can be proven.
\end{abstract}

Keyword: KPK; Criminal Liability Corruption; Political Party; Political Corruption.

\begin{abstract}
Abstrak
Ditengah gemilang langkah KPK menjalankan fungsi penegakan hukum pemberantasan Tipikor, masih ada yang terasa mengganjal. KPK belum atau tidak berani menjerat parpol dalam pertanggungjawaban pidana tipikor, memakai undang-undang tipikor. Pada setiap kasus berdimensi korupsi politik, KPK hanya menjerat elit partai, tapi tidak sekaligus menuntut pertanggungjawaban pidana tipikor parpol. Padahal, dalam beberapa kasus yang diusut, aliran dana mengalir ke partai politik. Sebagai delik khusus, membedah kembali UU Tipikor, dengan memasukkan frasa "badan hukum", selain frasa "setiap orang" diperlukan guna menemukan, atau membangun kanal untuk menjerat parpol dalam pertangungjawaban pidana tipikor, disertai sanksi pengembalian kerugian Negara dan denda. Sanksi administrasi juga bisa diterapkan melalui pembekuan melalui Kemenkumham atau pembubaran parpol tersebut melalui jalur Mahkamah Konstitusi ketika dakwaan dan tuntutan KPK tersebut bisa dibuktikan.
\end{abstract}

Kata kunci: KPK; Pertanggungjawaban Pidana Tipikor; Parpol; Korupsi Politik. 


\section{A. Latar Belakang Masalah}

Reformasi politik tahun 1998 pasca pengunduran diri Soeharto nyatanya belum sepenuhnya mampu mengubah secara radikal paradigma politik para elit politik, termasuk menekan laju korupsi politik yang semakin mengkhawatirkan. Meskipun skalanya tidak sebesar korupsi politik era Orba, namun korupsi politik pasca reformasi dan amandemen konstitusi, tetap saja menghambat agendaagenda konsolidasi politik, kaitannya dengan cita pemberantasan korupsi. Sebuah langkah maju diperlukan untuk menekan korupsi politik. Salah satunya dengan menjerat partai politik (parpol) dalam pertanggungjawaban pidana (criminal responsibility/ teorekenbaardheid) tindak pidana korupsi (tipikor).

Korupsi politik yang terjadi di Indonesia berkorelasi positif dengan kegiatan pencairan dana parpol untuk membiayai kegiatan politik partai, baik dalam skala nasional seperti Hambalang, Wisma Atlet, e-KTP, termasuk yang belum lama terjadi, kasus suap jual beli jabatan di Kementeria Agama (Kemenag) yang melibatkan Ketua Umum (Ketum) Partai Persatuan Pembangunan (PPP) Romahurmuzy (RMY), maupun skala lokal seperti dalam kasus korupsi kepala daerah; Ratu Atut (Banten), Rita Widyasari (Kaltim), Fuad Amin (Bangkalan), Zumi Zola (Jambi), dan masih banyak lagi.

Data KPK pada November 2018 menyebutkan sekitar $61.17 \%$ pelaku tipikor yang diproses KPK adalah aktor politik, atau tindak pidana korupsinya berdimensi korupsi politik (political corruption). ${ }^{1}$ Mereka yang diproses itu, terdiri dari 69 orang anggota DPR-RI, 149 orang anggota DPRD, 104 kepala daerah, dan 223 orang pihak lain yang terkait dalam perkara korupsi. Setalian, survey TI 2017 silam menyebutkan korupsi politik juga menjadi salah satu faktor yang berkontribusi turunnya indeks Political and Economic Risk Consultancy (PERC) hingga 3 poin. Riset itu menunjukan jika pihak dalam korupsi politik merupakan pihak yang berkolaborasi melakukan korupsi atau dalam case yang sama dimana aktor politik terjerat korupsi.

Sehingga menjadi masuk akal, jika isu pemberantasan korupsi, khususnya korupsi politik, tidak saja menjadi agenda nasional, tapi agenda global. Seperti yang tertuang dalam International Anti Corruption Conference (IACC) ke-8 di Lima, Peru pada 7-11 September 1997 bertema "Integritas Global

\footnotetext{
${ }^{1}$ https://nasional.kontan.co.id/news/kpk-6117-kasus-yang-ditangani-berdimensi-politik data akses Kamis 22 Maret 2019. Lihat pula Ismail Aris, dkk dalam artikelnya "Konstitusional Hak Angket DPR terhadap KPK" menyebutkan bahwa dalam termin waktu 11 tahun (2007-2018) terdapat 247 orang politisi yang tertangkap KPK. Sumber: Aris, Ismail, Irfan Amir, and Septian Amrianto. "Konstitusionalitas Hak Angket Dewan Perwakilan Rakyat (Dpr) Terhadap Komisi Pemberantasan Korupsi (Kpk)." Al-Adalah: Jurnal Hukum dan Politik Islam 4, no. 2 (2019): 135158.
} 
Mengembangkan Strategi Antikorupsi dalam Dunia yang Mengalami Perubahan”, menetapkan langkah-langkah pencegahan dan pemberantasan korupsi, antara lain;

"Karena korupsi sebagai penghalang utama dalam proses pemilu dan proses-proses politik, maka harus segera diambil tindakan untuk menerapkan cara-cara efektif yang mengatur sumbangan untuk politisi dan partai politik dan segera mencatatnya secara publik dan menetapkan batas-batas pengeluaran kampanye dan mengauditnya secara ketat serta melanjutkan program pendidikan kewarganegaraan menjadi sangat penting. "2

Berdasarkan uraian diatas, maka rumusan masalah dalam tulisan ini hendak mengkaji 2 (dua) pertanyaan utama; pertama, bagaimana praktik korupsi politik di Indonesia yang mengarah pada pembiayaan aktifitas partai politik (parpol) dari uang hasil kejahatan korupsi?; kedua, bagaimana merumuskan upaya hukum pidana dan administrasi untuk menuntut tanggungjawab (criminal liability) dan sanksi pidana dan administrasi bagi parpol yang melakukan kejahatan tipikor?

\section{B. Metode Penelitian}

Metode Penelitian adalah penelitian hukum normatif-yuridis, merujuk Peter Mahmud, bahwa penelitian hukum adalah suatu proses untuk menemukan aturan hukum, prinsip-prinsip hukum, maupun doktrin-doktrin hukum guna menjawab isu hukum yang dihadapi". ${ }^{3}$ Jenis penelitian dalam penelitian hukum ini adalah penelitian hukum normatif atau doktrinal. Menurut Terry Hutchinson sebagaimana dikutip Peter Mahmud Marzuki mendefinisikan bahwa penelitian hukum doktrinal adalah "doctrinal research: research wich provides a systematic exposition of the rules goverming a particular legal kategory, analyses the relationship between rules, explain areas of difficullty and, perhaps, predicts future development". (Penelitian doktrinal adalah penelitian yang memberikan penjelasan sistematis aturan yang mengatur suatu kategori hukum tertentu, menganalisis hubungan antara peraturan......). ${ }^{4}$ Penelitian normatif dalam artikel ini menganalisis UU Tindak Pidana Korupsi, UU Komisi Pemberantasan Korupsi, Peraturan Mahkamah Agung (PERMA) No.13 Tahun 2016, doktrin atau pendapat para ahli/pakar, kaitannya dengan kasus berdimensi korupsi politik yang melibatkan elit parpol dan parpol secara institusi, untuk mendorong pertanggungjawaban dan sanksi pidana; denda dan kerugian Negara, serta administrasi; pembekuan atau pembubaran melalui Mahkamah Konstitusi (MK).

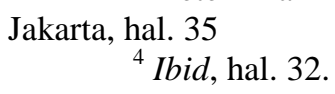
${ }^{4}$ Ibid, hal. 32.

${ }^{3}$ Peter Mahmud Marzuki, 2011, Penelitian Hukum, Kencana Prenada Media Group, 
Tujuan penelitian dalam artikel ini adalah; pertama, bagaimana mengurai praktik korupsi politik di Indonesia yang mengarah pada pembiayaan aktifitas partai politik (parpol) dari uang hasil kejahatan korupsi?; kedua, bagaimana merumuskan upaya hukum pidana dan administrasi untuk menuntut tanggungjawab dan sanksi pidana dan administrasi bagi parpol yang melakukan kejahatan tipikor?

\section{Pembahasan}

\section{Tafsir dan Praktik Korupsi Politik}

Hubungan korupsi dan politik bisa dirujuk dalam beberapa karya, salah satunya karya John Girling, peneliti senior dari Australian National University yang berjudul "Corruption, Capitalism and Democracy". ${ }^{5}$ Buku ini membahas kaitan antara perilaku korupsi yang tidak hanya melibatkan aktor pemerintah, tapi juga sektor bisnis dan politisi, termasuk parpol. Mereka menciptakan kongsi untuk berbagi sumberdaya. Daniel S. Lev, seorang Profesor Ilmu Politik dari University of Washington dan seorang Indonesianis, memberikan gambaran umum permainan politik dalam kasus korupsi politik, bahwa politik sering tidak berjalan sesuai dengan aturan hukum (rule of law), tetapi berlangsung sesuai dengan pengaruh, uang, keluarga, status sosial, dan kekuasan militer. ${ }^{6}$ Pendapat Lev ini mengisyaratkan adanya korelasi antara faktor tidak berfungsinya aturan hukum, permainan politik, tekanan kelompok dominan dengan faktor korupsi. Korupsi era Orde Baru (Orba) adalah contoh otentik praktik korupsi politik dalam skala yang sangat massif dan ekstrem.

Hoddes $^{7}$ mendefinisikan korupsi politik sebagai penyalahgunaan kekuasaan oleh pemimpin politik dengan mengakumulasi kekuasaan dan kekayaan serta untuk keuntungan pribadi. Korupsi politik tidak hanya dalam bentuk pertukaran uang tetapi juga berupa memperdagangkan pengaruh (trading influence) atau memberikan fasilitas yang meracuni politik dan mengancam demokrasi. Korupsi politik melibatkan berbagai macam kejahatan dan kecurangan oleh pemimpin politik, sebelum, selama dan sesudah menjabat. Korupsi ini berbeda dengan korupsi birokrasi atau korupsi kecil-kecilan dalam pelayanan publik karena pelakunya adalah pejabat politik yang terpilih melalui pemilihan umum yang mendapatkan otoritas untuk mengalokasikan sumberdaya publik dan bertanggungjawab mewakili kepentingan publik.

${ }^{5}$ Girling, John , 1997, “Corruption, Capitalism and Democracy”, Routledge Studies in Social and Political Thought.

${ }^{6}$ Lev, Daniel S.1990, Hukum dan Politik di Indonesia, LP3ES, Jakarta, hal. 135.

7 Roben Hoddes, "Introduction". Dalam Transparency International, 2004, "Global Corruption Report 2004”, Special Focus: Political Corruption, London, Sterling VA: Pluto Press\&Transparency International. 
Artidjo $^{8}$ menyebutkan bahwa analisa terhadap kasus korupsi politik di berbagai negara menunjukkan bahwa korupsi semacam ini memiliki dampak yang luas dibandingkan korupsi yang dilakukan oleh mereka yang tidak memiliki kekuasaan. Korupsi politik juga selalu berusaha untuk mempertahankan dan memperpanjang penyalahgunaan kekuasaan dan kebutuhan terhadap tatanan sosio politis membutuhkan peran control yang seimbang dalam pelaksanaan kekuasaan. Korupsi politik berhubungan dengan pelanggaran Hak Asasi Manusia (HAM) oleh kepala pemerintahan karena korupsi politik sangat erat kaitannya dengan mempertahankan atau melangsungkan kekuasaan.

Tesis Giding, Lev, Hoddes dan Artidjo terkonfirmasi dalam beberapa kasus korupsi politik; Hambalang, Wisma Atlet, Impor Daging Sapi, E-KTP, jual beli jabatan di Kementerian Agama (Kemenag) serta kasus korupsi politik lain yang disidik KPK. Beberapa diantaranya bahkan telah menjerat Ketua Umum Parpol. Pertama, Presiden Partai Keadilan Sejahtera (PKS) Luthfi Hasan Ishaq (LHI). LHI terjerat kasus suap pengurusan penambahan kuota impor daging sapi senilai Rp 1,3 miliar pada tahun 2013 lalu. Dia bersama rekannya, Ahmad Fathanah menerima suap dari Direktur Utama PT Indoguna Utama, Maria Elizabeth Liman. Luthfi secara sah dan meyakinkan melanggar Pasal 12 huruf a UU No. 31 Tahun 1999 tentang Pemberantasan Tindak Pidana Korupsi sebagaimana telah diubah dengan UU No. 20 Tahun 2001 juncto Pasal 55 Ayat 1 ke-1 KUHP. Luthfi juga dinilai terbukti melakukan tindak pidana pencucian uang saat menjabat anggota DPR RI 2004-2009 dan setelah tahun tersebut. Luthfi dianggap terbukti menyembunyikan harta kekayaannya, menempatkan, mentransfer, mengalihkan, atau membayarkan. Majelis hakim Pengadilan Tindak Pidana Korupsi akhirnya memvonis Luthfi dengan hukuman 16 tahun penjara dan denda Rp 1 miliar subsider 1 tahun penjara.

Kedua, korupsi yang menjerat Ketua Umum Partai Persatuan Pembangunan (PPP) Suryadharma Ali (SDA). SDA terbukti melakukan pidana korupsi dalam penyelenggaraan ibadah haji mulai dari penentuan petugas haji, pengangkatan petugas pendamping amirul hajj, pemondokan, memanfaatkan sisa kuota haji selama 2010-2013. SDA juga menyelewengkan dana operasional menteri Rp 1,8 miliar. Akibat perbuatannya tersebut negara mengalami kerugian sekitar Rp 27 miliar. Majelis Hakim Pengadilan Tindak Pidana Korupsi menjatuhkan hukuman 6 tahun penjara dan denda sebesar Rp 300 juta subsider 3 bulan kurungan penjara. Atas putusan ini, SDA mengajukan banding ke Pengadilan Tinggi DKI Jakarta. Tapi, SDA malah mendapat tambahan hukuman.

${ }^{8}$ Artidjo Alkostar, Korelasi Korupsi Politik Dengan Hukum dan Pemerintahan di Negara Modern (Telaah tentang Praktik Korupsi Politik dan Penanggulangannya), JURNAL HUKUM No. Edisi Khusus Vol. 16 Oktober 2009: 155 - 179. 
Majelis Hakim Pengadilan Tinggi DKI Jakarta memutuskan SDA divonis 10 tahun penjara.

Ketiga, korupsi yang menjerat Ketua Umum Partai Demokrat Anas Urbaningrum (AU) dalam kasus korupsi proyek pembangunan Hambalang dan berbagai proyek APBN. AU juga dijerat Tindak Pidana Pencucian Uang (TPPU). Anas terbukti melakukan perbuatan sebagaimana diatur dan diancam secara pidana dalam Pasal 12 huruf a UU No. 31 Tahun 1999 tentang Pemberantasan Tindak Pidana Korupsi sebagaimana telah diubah dengan UU No. 20 Tahun 2001 jo Pasal 64 KUHP, Pasal 3 UU No.8 Tahun 2010 tentang Pencegahan dan Pemberantasan Tindak Pidana Pencucian Uang (TPPU), serta Pasal 3 ayat (1) huruf c UU No. 15 Tahun 2002 jo UU No.25 Tahun 2003 tentang Tindak Pidana Pencucian Uang. Pengadilan Tindak Pidana Korupsi memvonis AU dengan hukuman 8 tahun penjara. AU mengajukan banding ke Pengadilan Tinggi DKI Jakarta. Majelis Hakim Pengadilan Tinggi DKI Jakarta meringankan hukuman Anas menjadi 7 tahun penjara. Tak juga puas, Anas mengajukan kasasi ke MA. Tapi bukan mendapat keringanan, majelis hakim malah menambah hukuman AU dua kali lipat. Hukuman AU diperberat menjadi 14 tahun penjara dan denda Rp 5 miliar subsider penjara 1 tahun 4 bulan. Selain itu, AU wajib membayar uang pengganti Rp 57.592.330.580 kepada negara. Hakim juga mencabut hak politiknya. MA juga menolak keberatan AU yang menyatakan, tindak pidana asal dalam tindak pidana pencucian uang (TPPU) harus dibuktikan terlebih dahulu. Penolakan hakim berdasarkan pada Pasal 69 UU No.8 Tahun 2010 tentang Pencegahan dan Pemberantasan Tindak Pidana Pencucian Uang yang menegaskan bahwa tindak pidana asal tidak wajib dibuktikan terlebih dahulu.

Keempat, korupsi yang menjerat Ketua Umum Partai Golkar Setya Novanto (SN). Pada 31 Oktober 2017, SN menjadi tersangka mega skandal korupsi pengadaan e-KTP tahun 2011-2012 pada Kementerian Dalam Negeri yang merugikan negara $\mathrm{Rp} 2,3$ triliun. Ia disangka melakukan perbuatan itu bersama dengan Anang Sugiana Sudihardjo, Andi Agustinus alias Andi Narogong, Irman, Sugiharto, dan kawan-kawan. SN dikenakan Pasal 2 ayat 1 atau Pasal 3 Undang-Undang Pemberantasan Tindak Pidana Korupsi juncto Pasal 55 ayat 1 ke-1 KUHP. Di pengadilan Tipikor, ia divonis 15 tahun penjara, dan denda 1 miliar.

Kelima, korupsi yang menjerat Ketua Umum Partai Persatuan Pembangunan (PPP), sekaligus anggota DPR RI, Romahurmuzy (RMY). RMY ditangkap disebuah hotel di Surabaya pada Jumat (16/03/2019) lalu. Bersama RMY juga diamankan sejumlah pejabat wilayah Kemenag. Pada Januari 2020, RMY divonis 2 tahun penjara oleh Majelis Hakim Pengadilan tipikor karena terbukti menerima suap 255 Juta dalam skandal jual beli jabatan di Kementerian 
Agama (Kemenag). Tidak sampai di RMY, KPK sementara mengembangkan kasus ini untuk mempelajari keterlibatan aktor lain.

Korupsi juga menjerat sejumlah kepala daerah hasil pemilukada dari unsur parpol. Dalam kurun waktu 2004-2015, KPK sudah memenjarakan 64 kepala daerah, dengan rincian 15 gubernur, 49 bupati/wali kota. ${ }^{9}$ Jumlah ini belum ditambah dengan kepala daerah yang ditangkap KPK dalam sejumlah operasi tangkap tangan (OTT) pada kurun waktu 2016- 2018. Pada tahun 2016, ada 10 kepala daerah jadi tersangka kasus korupsi. Pada tahun 2017, ada 6 kepala daerah yang jadi tersangka korupsi di KPK. Pada 2018 angka ini meningkat menjadi 29 kepala daerah terjerat kasus korupsi (lihat tabel).

Tabel 1: Daftar kepala daerah terjerat kasus Tipikor tahun 2016

\begin{tabular}{|c|c|c|c|c|}
\hline No & Kepala Daerah & Partai & Kasus & Keterangan \\
\hline 1 & $\begin{array}{l}\text { Ojang Sohandi } \\
\text { (Bupati Subang) }\end{array}$ & PDIP & $\begin{array}{l}\text { Kasus suap kepada JPU } \\
\text { penyidikan anggaran } \\
\text { BPJS Kesehatan sebesar } \\
528 \text { juta tahun } 2014 \text {. }\end{array}$ & $\begin{array}{l}\text { Divonis } 8 \text { tahun } \\
\text { penjara }\end{array}$ \\
\hline 2 & $\begin{array}{l}\text { Suparman } \\
\text { (Bupati Rokan Hulu) }\end{array}$ & GOLKAR & $\begin{array}{l}\text { Kasus Gratifikasi pemba- } \\
\text { hasan RAPBD Rokan } \\
\text { Hulu Tahun 204-2015. }\end{array}$ & $\begin{array}{l}\text { Divonis } 4,5 \text { ta- } \\
\text { hun penjara }\end{array}$ \\
\hline 3 & $\begin{array}{l}\text { Nur Alam } \\
\text { (Gubernur Sultra) }\end{array}$ & PAN & $\begin{array}{l}\text { Korupsi penyalahgunaan } \\
\text { izin tambang di Sultra. }\end{array}$ & $\begin{array}{l}\text { Divonis } 15 \text { ta- } \\
\text { hun penjara, di } \\
\text { sunat MA (Ka- } \\
\text { sasi) jadi } 12 \text { ta- } \\
\text { hun penjara }\end{array}$ \\
\hline 4 & $\begin{array}{l}\text { Yan Anton Ferdian } \\
\text { (Bupati Banyuasin) }\end{array}$ & GOLKAR & $\begin{array}{l}\text { Suap proyek Dinas } \\
\text { Pendi-dikan dan dinas } \\
\text { lainnya di Banyuasin. }\end{array}$ & $\begin{array}{l}\text { Divonis } 6 \text { tahun } \\
\text { penjara }\end{array}$ \\
\hline 5 & $\begin{array}{l}\text { Bambang Irianto } \\
\text { (Walikota Madiun) }\end{array}$ & DEMOKRAT & $\begin{array}{l}\text { Menerima gratifkasi saat } \\
\text { menjabat sebagai wali- } \\
\text { kota tahun } 2009-2014 \text {. }\end{array}$ & $\begin{array}{l}\text { Divonis } 6 \text { tahun } \\
\text { penjara }\end{array}$ \\
\hline 6 & $\begin{array}{l}\text { Bambang Kurniawan } \\
\text { (Bupati Tanggamus) }\end{array}$ & PDIP & $\begin{array}{l}\text { Suap kepada anggota } \\
\text { DPRD Tanggamus untuk } \\
\text { penyusunan APBD Ta- } \\
\text { hun } 2016 .\end{array}$ & $\begin{array}{l}\text { Divonis } 2 \text { tahun } \\
\text { penjara }\end{array}$ \\
\hline
\end{tabular}




\begin{tabular}{|c|c|c|c|c|}
\hline No & Kepala Daerah & Partai & Kasus & Keterangan \\
\hline 7 & $\begin{array}{l}\text { Marthen Dira Tome } \\
\text { (Bupati Sabu Raijua) }\end{array}$ & NASDEM & $\begin{array}{l}\text { Korupsi dana Pendidikan } \\
\text { Luar Sekolah (PLS) NTT. }\end{array}$ & $\begin{array}{l}\text { Divonis } 7 \text { tahun } \\
\text { penjara (tingkat } \\
\text { kasasi) }\end{array}$ \\
\hline 8 & $\begin{array}{l}\text { Sjamsu Umar Samiun } \\
\text { (Bupati Buton) }\end{array}$ & PAN & $\begin{array}{l}\text { Suap kepada Hakim } \\
\text { Konstitusi Akil Mochtar } \\
\text { dalam sengketa Pilkada } \\
\text { Buton. }\end{array}$ & $\begin{array}{l}\text { Divonis } 3,9 \text { ta- } \\
\text { hun penjara }\end{array}$ \\
\hline 9 & $\begin{array}{l}\text { Atty Suhari } \\
\text { (Walikota Cimahi) }\end{array}$ & PKS & $\begin{array}{l}\text { Menerima suap proyek } \\
\text { pembangunan tahap II } \\
\text { Pasar Atas Baru Cimahi. }\end{array}$ & $\begin{array}{l}\text { Divonis } 4 \text { tahun } \\
\text { penjara }\end{array}$ \\
\hline 10 & $\begin{array}{l}\text { Taufiqurrahman } \\
\text { (Bupati Nganjuk) }\end{array}$ & PDIP & $\begin{array}{l}\text { Korupsi proyek infras- } \\
\text { truktur Kab Nganjuk } \\
\text { tahun 2009. }\end{array}$ & $\begin{array}{l}\text { Divonis } 7 \text { tahun } \\
\text { penjara }\end{array}$ \\
\hline
\end{tabular}

Ket: dirangkum dari berbagai sumber

Tabel 2: Daftar kepala daerah terjerat kasus tipikor tahun 2017

\begin{tabular}{|c|c|c|c|c|}
\hline No & Kepala Daerah & Partai & Kasus & Keterangan \\
\hline 1 & $\begin{array}{l}\text { Ridwan Mukti } \\
\text { (Gubernur Bengkulu) }\end{array}$ & GOLKAR & $\begin{array}{l}\text { Suap proyek peningkatan } \\
\text { jalan TES-Myara Aman }\end{array}$ & $\begin{array}{l}\text { Divonis } 9 \text { tahun } \\
\text { penjara (tingkat } \\
\text { banding) }\end{array}$ \\
\hline 2 & $\begin{array}{l}\text { Achmad Syafii } \\
\text { (Bupati Pamekasan) }\end{array}$ & DEMOKRAT & $\begin{array}{l}\text { Korupsi suap penyelewe- } \\
\text { ngan dana desa sebesar } \\
100 \text { juta }\end{array}$ & $\begin{array}{l}\text { Divonis } 2,8 \text { ta- } \\
\text { hun penjara }\end{array}$ \\
\hline 3 & $\begin{array}{l}\text { Siti Masitha } \\
\text { (Walikota Tegal) }\end{array}$ & GOLKAR & $\begin{array}{l}\text { Suap pengelolaan dana } \\
\text { jasa pelayanan RSUD } \\
\text { Kardinah Kota Tegal }\end{array}$ & $\begin{array}{l}\text { Divonis } 5 \text { tahun } \\
\text { penjara }\end{array}$ \\
\hline 4 & $\begin{array}{l}\text { OK Arya Zulkarnaen } \\
\text { (Bupati Batubara) }\end{array}$ & GOLKAR & $\begin{array}{l}\text { Suap pembangunan infra- } \\
\text { struktur di Kab Batu-bara } \\
\text { tahun } 2017 .\end{array}$ & $\begin{array}{l}\text { Divonis } 5,6 \text { ta- } \\
\text { hun penjara }\end{array}$ \\
\hline 5 & $\begin{array}{l}\text { Eddy Rumpoko } \\
\text { (Walikota Batu- } \\
\text { Malang) }\end{array}$ & PDIP & $\begin{array}{l}\text { Suap proyek belanja mo- } \\
\text { dal dan mesin pengadaan } \\
\text { meubelair TA } 2017 \\
\text { senilai Rp.5,26 miliar }\end{array}$ & $\begin{array}{l}\text { Divonis } 5,5 \text {, ta- } \\
\text { hun penjara }\end{array}$ \\
\hline
\end{tabular}


Tabel 3: Daftar kepala daerah terjerat kasus tipikor tahun 2018

\begin{tabular}{|c|c|c|c|c|}
\hline No & Kepala Daerah & Parpol & Kasus & Keterangan \\
\hline 1 & $\begin{array}{l}\text { Marianus Sae } \\
\text { Bupati Ngada, NTT }\end{array}$ & PDIP & $\begin{array}{l}\text { Suap proyek jalan di } \\
\text { Ngada, NTT }\end{array}$ & $\begin{array}{l}\text { Divonis } 8 \text { tahun } \\
\text { penjara }\end{array}$ \\
\hline 2 & $\begin{array}{l}\text { Adriatma Dwi Putra } \\
\text { (Walikota Kendari) }\end{array}$ & PAN & $\begin{array}{l}\text { Suap Pengadaan Barang } \\
\text { dan Jasa di Kota Kendari. }\end{array}$ & $\begin{array}{l}\text { Divonis } 5,5 \text {, ta- } \\
\text { hun penjara }\end{array}$ \\
\hline 3 & $\begin{array}{l}\text { Rita Widyasari } \\
\text { (Bupati Kutai Kerta- } \\
\text { negara) }\end{array}$ & PDIP & Suap dan gratifikasi & $\begin{array}{l}\text { Divonis } 10 \text { ta- } \\
\text { hun penjara }\end{array}$ \\
\hline 4 & $\begin{array}{l}\text { Taufiqurrahman } \\
\text { (Bupati Nganjuk) }\end{array}$ & PDIP & Suap dan gratifikasi & $\begin{array}{l}\text { Divonis } 7 \text { tahun } \\
\text { penjara }\end{array}$ \\
\hline 5 & $\begin{array}{l}\text { Irvan Rivano Muchtar } \\
\text { (Bupati Cianjur) }\end{array}$ & NASDEM & $\begin{array}{l}\text { Korupsi DAK Pendidikan } \\
\text { Kab Cianjur. }\end{array}$ & Belum vonis \\
\hline 6 & $\begin{array}{l}\text { Ahmad Marzuki } \\
\text { (Bupati Jepara) }\end{array}$ & PPP & $\begin{array}{l}\text { Menyuap hakim PN Se- } \\
\text { marang. }\end{array}$ & Belum vonis \\
\hline 7 & $\begin{array}{l}\text { Remigo Yolando } \\
\text { Berutu } \\
\text { (Bupati Pakpak } \\
\text { Bharat) }\end{array}$ & DEMOKRAT & $\begin{array}{l}\text { Menerima suap dari pihak } \\
\text { swasta. }\end{array}$ & Belum vonis \\
\hline 8 & $\begin{array}{l}\text { Sunjaya } \\
\text { Purwadisastra } \\
\text { (Bupati Cirebon) }\end{array}$ & PDIP & $\begin{array}{l}\text { Sunjaya menjadi tersang- } \\
\text { ka Menerima suap dan } \\
\text { gratifikasi penempatan ja- } \\
\text { batan di Kabup Cirebon. }\end{array}$ & Belum vonis \\
\hline 9 & $\begin{array}{l}\text { Neneng Hassanah } \\
\text { Yasin } \\
\text { (Bupati Bekasi) }\end{array}$ & GOLKAR & $\begin{array}{l}\text { Menerima suap dari pihak } \\
\text { swasta terkait pemba- } \\
\text { ngunan Meikarta }\end{array}$ & Belum vonis \\
\hline 10 & $\begin{array}{l}\text { Rendra Kresna } \\
\text { (Bupati Malang) }\end{array}$ & NASDEM & $\begin{array}{l}\text { Menerima suap terkait } \\
\text { pembangunan prasarana } \\
\text { pendidikan di Malang }\end{array}$ & Belum vonis \\
\hline 11 & $\begin{array}{l}\text { Setiyono } \\
\text { (Walikota Pasuruan) }\end{array}$ & GOLKAR & $\begin{array}{l}\text { Menerima suap dari pihak } \\
\text { swasta terkait PBJ pada } \\
\text { dinas koperasi dan } \\
\text { UMKM Pasuruan }\end{array}$ & Belum vonis \\
\hline
\end{tabular}




\begin{tabular}{|c|c|c|c|c|}
\hline No & Kepala Daerah & Parpol & Kasus & Keterangan \\
\hline 12 & $\begin{array}{l}\text { Zainuddin Hasan } \\
\text { (Bupati Lampung } \\
\text { Selatan) }\end{array}$ & PAN & $\begin{array}{l}\text { Menerima suap dari pihak } \\
\text { swasta terkait pembangu- } \\
\text { nan infrastruktur di Lam- } \\
\text { pung Selatan }\end{array}$ & Belum vonis \\
\hline 13 & $\begin{array}{l}\text { Pangonal Harahap } \\
\text { (Bupati Labuhan } \\
\text { Batu) }\end{array}$ & PDIP & $\begin{array}{l}\text { Menerima suap dari pihak } \\
\text { swasta terkait beberapa } \\
\text { proyek di Labuhanbatu } \\
\text { tahun } 2018\end{array}$ & Belum vonis \\
\hline 14 & $\begin{array}{l}\text { Ahmadi } \\
\text { (Bupati Bener } \\
\text { Meriah) }\end{array}$ & GOLKAR & $\begin{array}{l}\text { Bersama Gubernur Aceh, } \\
\text { Irwandi Yusuf menerima } \\
\text { fee proyek yang dananya } \\
\text { berasal dari dana Otsus } \\
\text { Aceh }\end{array}$ & $\begin{array}{l}\text { Divonis } 3 \text { tahun } \\
\text { penjara }\end{array}$ \\
\hline 15 & $\begin{array}{l}\text { Irwandi Yusuf } \\
\text { (Gubernur Aceh) }\end{array}$ & PAN & $\begin{array}{l}\text { Bersama Bupati Bener } \\
\text { Meriah, Ahmadi, meneri- } \\
\text { ma fee proyek yang da- } \\
\text { nanya berasal dari dana } \\
\text { Otsus Aceh. Irwandi juga } \\
\text { menyalahgunakan angga- } \\
\text { ran pembangunan derma- } \\
\text { ga Sabang }\end{array}$ & Belum vonis \\
\hline 16 & $\begin{array}{l}\text { Samanhudi Anwar } \\
\text { (Walikota Blitar) }\end{array}$ & PDIP & $\begin{array}{l}\text { Menerima suap dari pihak } \\
\text { swasta }\end{array}$ & $\begin{array}{l}\text { Divonis } 5 \text { tahun } \\
\text { penjara }\end{array}$ \\
\hline 17 & $\begin{array}{l}\text { Syahri Mulyo } \\
\text { (Bupati Tulungagung) }\end{array}$ & PDIP & $\begin{array}{l}\text { Menerima suap dari pihak } \\
\text { swasta }\end{array}$ & $\begin{array}{l}\text { Divonis } 10 \text { ta- } \\
\text { hun }\end{array}$ \\
\hline 18 & $\begin{array}{l}\text { Tasdi } \\
\text { (Bupati Purbalingga) }\end{array}$ & PDIP & $\begin{array}{l}\text { Menerima gratifikasi dari } \\
\text { swasta terkait pembangu- } \\
\text { nan Purbalingga Islamic } \\
\text { Centre }\end{array}$ & $\begin{array}{l}\text { Divonis } 7 \text { tahun } \\
\text { penjara }\end{array}$ \\
\hline 19 & $\begin{array}{l}\text { Agus Feisal Hidayat } \\
\text { (Bupati Buton } \\
\text { Selatan) }\end{array}$ & PDIP & $\begin{array}{l}\text { Menerima suap dan gra- } \\
\text { tifikasi dari pihak swasta } \\
\text { terkait berbagai proyek di } \\
\text { Busel }\end{array}$ & $\begin{array}{l}\text { Divonis } 8 \text { tahun } \\
\text { penjara }\end{array}$ \\
\hline
\end{tabular}




\begin{tabular}{|c|c|c|c|c|}
\hline No & Kepala Daerah & Parpol & Kasus & Keterangan \\
\hline 20 & $\begin{array}{l}\text { Mustofa Kemal Pasha } \\
\text { (Bupati Mojokerto) }\end{array}$ & PDIP & $\begin{array}{l}\text { Menerima suap dari pihak } \\
\text { swasta terkait pembangu- } \\
\text { nan menara telekomuni- } \\
\text { kasi di Mojokerto }\end{array}$ & $\begin{array}{l}\text { Divonis } 8 \text { tahun } \\
\text { penjara }\end{array}$ \\
\hline 21 & $\begin{array}{l}\text { Dirwan Mahmud } \\
\text { (Bupati Bengkulu } \\
\text { Selatan) }\end{array}$ & PERINDO & $\begin{array}{l}\text { Menerima suap dari pihak } \\
\text { swasta }\end{array}$ & $\begin{array}{l}\text { Divonis } 6 \text { tahun } \\
\text { penjara }\end{array}$ \\
\hline 22 & $\begin{array}{l}\text { Abubakar } \\
\text { (Bupati Bandung } \\
\text { Barat) }\end{array}$ & PDIP & $\begin{array}{l}\text { Menerima suap dari bebe- } \\
\text { rapa kepala dinas untuk } \\
\text { keperluan istri mencalon- } \\
\text { kan diri sebagai calon } \\
\text { Bupati Bandung Barat. }\end{array}$ & $\begin{array}{l}\text { Divonis } 5,5 \text {, ta- } \\
\text { hun }\end{array}$ \\
\hline 23 & $\begin{array}{l}\text { Mustafa } \\
\text { (Bupati Lampung } \\
\text { Tengah) }\end{array}$ & NASDEM & $\begin{array}{l}\text { Mengumpulkan uang dan } \\
\text { memerintahkan jajaran- } \\
\text { nya untuk memberi suap } \\
\text { kepada sejumlah anggota } \\
\text { DPRD Lampung Tengah. }\end{array}$ & $\begin{array}{l}\text { Divonis } 3 \text { tahun } \\
\text { penjara }\end{array}$ \\
\hline 24 & $\begin{array}{l}\text { Imas Aryumningsih } \\
\text { (Bupati Subang) }\end{array}$ & GOLKAR & $\begin{array}{l}\text { Menerima suap dari pihak } \\
\text { swasta terkait perizinan }\end{array}$ & $\begin{array}{l}\text { Divonis } 6,5 \text { ta- } \\
\text { hun penjara }\end{array}$ \\
\hline 25 & $\begin{array}{l}\text { Nyono Suharli } \\
\text { Wihandoko } \\
\text { (Bupati Jombang) }\end{array}$ & GOLKAR & $\begin{array}{l}\text { Suap terkaiut perizinan } \\
\text { dan penempatan jabatan } \\
\text { di Pemkab Jombang }\end{array}$ & $\begin{array}{l}\text { Divonis } 3,5 \text { ta- } \\
\text { hun penjara }\end{array}$ \\
\hline 26 & $\begin{array}{l}\text { Zumi Zola } \\
\text { (Gubernur Jambi) }\end{array}$ & PAN & $\begin{array}{l}\text { Menerima suap untuk } \\
\text { menyuap anggota DPRD } \\
\text { Jambi guna pengesahan } \\
\text { RAPBD Jambi } 2018\end{array}$ & $\begin{array}{l}\text { Divonis } 6 \text { tahun } \\
\text { penjara }\end{array}$ \\
\hline 27 & $\begin{array}{l}\text { Abdul Latif } \\
\text { (Bupati Hulu Sungai } \\
\text { Tengah) }\end{array}$ & BERKARYA & $\begin{array}{l}\text { Suap terkait pembangu- } \\
\text { nan RSUD HST }\end{array}$ & $\begin{array}{l}\text { Divonis } 6 \text { tahun } \\
\text { penjara }\end{array}$ \\
\hline 28 & $\begin{array}{l}\text { Mohammad Yahya } \\
\text { Fuad } \\
\text { (Bupati Kebumen) }\end{array}$ & - & $\begin{array}{l}\text { Menerima suap dan gra- } \\
\text { tifikasi terkait beberapa } \\
\text { proyek di Kebumen }\end{array}$ & $\begin{array}{l}\text { Divonis } 4 \text { tahun } \\
\text { penjara }\end{array}$ \\
\hline 29 & $\begin{array}{l}\text { Rudy Erawan } \\
\text { (Bupati Halmahera }\end{array}$ & PDIP & $\begin{array}{l}\text { Menerima suap dari pihak } \\
\text { swasta terkait pembangu- }\end{array}$ & $\begin{array}{l}\text { Divonis } 4,5 \text { tah- } \\
\text { un penjara }\end{array}$ \\
\hline
\end{tabular}




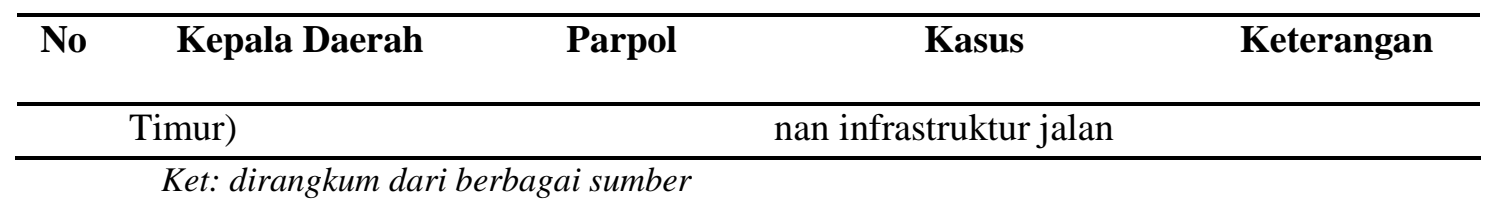

Data ini belum termasuk nama kepala daerah lintas parpol yang terjerat korupsi sejak 2004-2006; Abdulah Puteh, Gubernur NAD (2004), Suwarna Abdul Fatah, Gubernur Kalimantan Timur (2005), Sjahriel Darham, Gubernur Kalimantan Selatan (2006), Abubakar Ahmad, Bupati Dompu (2006), Hendy Boedoro, Bupati Kendal (2006), Syaukani Hr, Bupati Kutai Kartanegara (2006). Tahun 2007-2009; Baso Amiruddin Maula, Wali Kota Makassar (2007), Abdillah, Wali Kota Medan (2007), Ramli, Wakil Wali Kota Medan (2007), Tengku Azmun Jaafar, Bupati Pelalawan (2007), Agus Supriadi, Bupati Garut (2007), Vonnie A Panambunan, Bupati Minahasa Utara (2007), Saleh Djasit, Gubernur Riau (2007), Iskandar, Bupati Lombok Barat (2008), Daud Solleman Betawi, Bupati Yapen Waropen (2008), Armen Desky, Bupati Aceh Tenggara (2008), Jimmy Rimba Rogi, Wali Kota Manado (2008), Samsuri Aspar, Wakil Bupati Kutai Kartanegara (2008), Ismunarso, Bupati Situbondo (2008), Jules F Warikar, Bupati Supiori (2009), Ha Hamid Rizal, Mantan Bupati Natuna (2009), H Daeng Rusnadi, Bupati Natuna (2009), Arwin As, Bupati Siak (2009), Indra Kusuma, Bupati Brebes (2009), Syahrial Oesman, Gubernur Sumatera Selatan (2009).

Tahun 2010-2012; Yusak Yaluwo, Bupati Boven Digoel (2010), Mochtar Mohamad, Wali Kota Bekasi (2010), Binahati B Baeha, Bupati Nias (2010), Fahuwusa Laila, Bupati Nias Selatan (2011), Murman Effendi, Bupati Seluma (2011), Robert Edison Siahaan, Mantan Wali Kota Pematang Siantar (2011), Soemarmo Hadi Saputro, Wali Kota Semarang (2012), Aat Syafaat, Mantan Wali Kota Cilegon (2012), Jefferson Soleiman Montesqieu Rumajar, Wali Kota Tomohon (2012), dan Amran Batalipu, Bupati Buol (2012). Tahun 2013-2015; Muhammad Hidayat Batubara, Bupati Mandailing Natal (2013), Dada Rosada, Wali Kota Bandung (2013), Hambit Bintih, Bupati Gunung Mas (2013), Rusli Zainal, Gubernur Riau (2013), Ikmal Jaya, Wali Kota Tegal (2014), Ilham Arief Siradjudin, Wali Kota Makassar (2014), Rachmat Yasin, Bupati Bogor (2014), Romi Herton, Wali Kota Palembang (2014), Yesaya Sombuk, Bupati Biak Numfor (2014), Ade Swara, Bupati Karawang (2014), Raja Bonaran Situmeang, Bupati Tapanuli Tengah (2014), Amir Hamzah, Wakil Bupati Lebak (2014), Zaini Arony, Bupati Lombok Barat (2014), H Fuad Amin, Bupati Bangkalan (2014), Ratu Atut Chosiyah, Gubernur Banten (2014), Barnabas Suebu , Gubernur Papua (2014), Annas Maamun, Gubernur Riau (2014), Gatot Pujo Nugroho, Gubernur Sumatera Utara (2015), Budi Antoni Aljufri, Bupati Empat Lawang (2015), Rusli 
Sibua, Bupati Pulau Morotai (2015), dan Pahri Azhari, Bupati Musi Banyuasin $(2015){ }^{10}$

Data itu menunjukan bahwa kasus korupsi politik di Indonesia cukup tinggi. Praktik korupsi politik di Indonesia, dan juga dihampir semua Negara di dunia, adalah "habitus" pertemuan dua senyawa, sekaligus menciptakan hubungan saling ketergantungan (simbiosis mutualisme) yang koruptif; parpol dan kader (elit). Parpol menjadi entitas dominan yang mempengaruhi munculnya korupsi. Mengapa? Karena temuan korupsi politik menyebutkan korupsi dilakukan untuk membiayai kegiatan-kegiatan politik, baik pribadi kader partai, maupun untuk kegiatan-kegiatan politik partai.

Sehingga, sulit memisahkan kaitan antara parpol dan kadernya dalam praktik korupsi politik. Memisahkan keduanya sama dengan memisahkan lautan dengan garam. Saya sebut Parpol entitas dominan karena dalam sebagian besar kasus korupsi yang diusut KPK melibatkan "orang-orang politik". Mereka bisa mengenakan atribut partai (politisi) atau yang berafiliasi dengan partai atau politisinya. Dalam kasus korupsi politik yang diangkat, terlihat benang merah yang mengarah pada pembiayaan aktifitas politik partai. Praktik rent seeking ini dilakukan oleh hampir semua kader parpol ketika menduduki posisi penting pemerintahan, baik di pusat maupun di daerah.

Di lembaga negara, sumberdaya parpol tersebar di berbagai lembaga; mulai dari Presiden, DPR, DPRD hingga Menteri. Undang-undang mensyaratkan presiden diusulkan parpol. Demikian pula dengan DPR dan DPRD Prop/Kab/Kota, semuanya dari parpol, terkecuali DPD. Beberapa Menterti Negara juga berasal dari unsur parpol. Demikian pula di sejumlah BUMN/BUMD strategis, beberapa komisionernya dari parpol. Ada "kontrak" dengan parpol yang menjadi habitus politiknya, untuk membantu mencarikan dana guna membiayai kebutuhan politik partai.

\section{Pertanggungjawaban dan Sanksi Pidana}

Diskursus sanksi pidana bagi parpol yang terbukti menerima aliran dana hasil kejahatan tipikor bukanlah hal baru. Sudah banyak tulisan dan kajian yang mencoba mendorong penerapan sanksi pidana bagi parpol dalam aliran dana korupsi. Semua sepakat bahwa parpol harus dibebankan tanggungjawab pidana dan diberi sanksi pidana denda, maupun sanksi administrasi seperti pembekuan atau pembubaran melalui Mahkamah Konstitusi (MK), ${ }^{11}$ jika skala korupsinya sangat massif. Akan tetapi, persoalannya tidak sesederhana itu, semua kajian pada isu ini menemui jalan buntu pada satu pertanyaan kunci, bagaimana

10 https://www.idntimes.com/news/indonesia/lia-hutasoit/daftar-lengkap-100-kepala-daerah-ditangkap-kpk-sejak/full data akses 23 Maret 2019 pukul 16.15 wita.

${ }^{11}$ Salah satu kewenangan MK dalam UU MK No 24 Tahun 2003 sebagimana telah diubah dengan UU No 8 Tahun 2011 adalah memutus pembubaran partai politik. 
menyimpulkan bahwa korupsi yang dilakukan elit partai itu sekaligus adalah tindakan partai politiknya? Mengingat selama ini saat publik menuntut pertanggungjawaban pidana terhadap parpol, maka elit yang lain akan membantah dengan mengatakan bahwa itu adalah tindakan pribadi kader, bukan partai, sementara fakta menunjukan ada aliran dana yang mengarah ke parpol.

Pada beberapa kasus korupsi politik yang melibatkan elit partai yang disidik KPK, terdapat benang merah yang mengarah pada pembiayaan aktifitas partai. Seperti saat KPK menyidik Anas Urbaningrum (AU), Muh. Nazaruddin (MN) dalam kasus korupsi Hambalang, kesaksian Nazaruddin jika uang yang dipakai AU untuk memenangkan dirinya dalam kongres tersebut berasal dari proyek Hambalang. Setya Novanto (SN) saat memberikan kesaksian selaku terdakwa di Pengadilan Tipikor (22/03/2018), mengaku jika ada aliran uang korupsi proyek e-KTP sebesar 5 miliar mengalir ke Rapimnas Golkar.

Dalam kasus korupsi proyek Pembangkit Listrik Tenaga Uap (PLTU) Mulut Tambang Riau-1 yang menyeret sejumlah pengurus Partai Golkar; Eni Maulani Saragih, mantan Sekjen Partai Golkar Idrus Marham, dan pengusaha Johannes Budisutrisno Kotjo selaku konsultan dan pemilik saham di perusahaan asal Singapura, BlackGold Natural Resources, terkuak fakta dari pengakuan Eni Maulani bahwa sebagian uang pemberian Kotjo mengalir ke panitia Munaslub Partai Golkar, Desember 2017 lalu. Eni jadi bendahara dalam perhelatan itu. Indikasi aliran dana itu cukup kuat karena Partai Golkar sudah mengembalikan uang Rp700 juta ke KPK. Kuasa Hukum Eni, M. Fadli Nasution membenarkan adanya pengembalian uang tersebut.

Bupati Purbalingga nonaktif, Tasdi, saat menjadi saksi dari 4 terdakwa, Kepala ULP Pemkab Purbalingga Hadi Iswanto, dan pihak swasta yaitu Hamdani Kosen, Librata Nababan, dan Adirawinata Nababan, dalam sidang perkara korupsi pembangunan Purbalingga Islamic Center, mengatakan jika uang korupsi tersebut digunakan untuk kegiatan PDI Perjuangan Purbalingga yang saat itu dipimpinnya. Pengakuan Wa Ode Nurhayati, terpidana 5,5 tahun dalam kasus korupsi dana PPID (Percepatan Pembangunan Infrastruktur Daerah), pernah melapor ke KPK pada Senin (17/9/2018) lalu. Ia menyatakan, kasus korupsi yang menjeratnya belum tuntas. Sebab, selain soal uang suap Rp6 miliar yang menyeretnya pada 2012, Wa Ode menilai ada dana Rp120 miliar yang diterima partainya, tapi belum diusut.

Pengakuan itu harus dikejar dan didalami untuk menyeret parpol ke meja hijau. Menjawab ini mesti dengan pisau analisis yang tajam, sehingga perlu membedah ulang UU Tipikor dan KUHPidana untuk menemukan - atau bahkan merumuskan - kanal baru untuk menjerat parpol. Sehingga ada shock therapy, parpol tidak bisa berlindung dibalik alibi "tanggungjawab kader". Parpol tidak 
bisa selamanya meng-kambinghitamkan kader. Ini juga penting dalam rangka konsolidasi politik hubungannya dengan cita pemberantasan korupsi.

Pada beberapa instrument hukum, baik global maupun nasional, sebetulnya sudah menyediakan kanal untuk membawa parpol korup ke meja hijau. Misalnya, dalam article 26 United Nations Convention Against Corruption (UNCAC), 2003 menyebut:

Negara-negara peserta mengambil langkah yang diperlukan untuk menentukan tanggungjawab badan-badan hukum yang ikut serta melakukan tindak pidana yang dilarang dalam konvensi ini. Tanggung jawab terhadap badan-badan hukum tersebut dapat bersifat pidana, perdata atau administratif. Bahkan setiap negara peserta harus memastikan bahwa badan-badan hukum yang bertanggung jawab tersebut tunduk pada sanksi-sanksi pidana dan nonpidana yang efektif, proporsional dan yang bersifat mencegah termasuk sanksi moneter.

UNCAC telah memasukan badan hukum yang melakukan kejahatan tipikor, sebagai subjek terperiksa yang bisa dijatuhi sanksi; pidana, perdata, atau administrasi (pembekuan atau pembubaran). Demikian pula, dalam UU Parpol No 2 Tahun 2008, Pasal 40 ayat (3) huruf (e) tertuang larangan bagi parpol untuk:

"menggunakan fraksi di Majelis Permusyawaratan Rakyat, Dewan Perwakilan Rakyat, Dewan Perwakilan Rakyat Daerah provinsi, dan Dewan Perwakilan Rakyat Daerah kabupaten/kota sebagai sumber pendanaan Partai Politik”.

Ayat (d) nya juga mengatur larangan parpol untuk "meminta atau menerima dana dari badan usaha milik negara, badan usaha milik daerah, dan badan usaha milik desa atau dengan sebutan lainnya'. Meskipun faktanya ada banyak praktek kader parpol di fraksi MPR, DPR, DPRD Prop/Kab/Kota, yang melakukan kegiatan-kegiatan rent seeking dengan membajak APBN/APBD untuk membiayai aktifitas partai. Termasuk beberapa kader partai di BUMN/BUMD yang juga melakukan praktik yang sama.

Problemnya ada di UU Pemberantasan Tindak Pidana Korupsi No 31Tahun 1999 jo UU No 20 Tahun 2001 yang hanya membebankan tanggungjawab pidana terhadap orang (penyelenggara Negara, penegak hukum, ASN, swasta) dan korporasi, partai politik tidak termasuk dalam badan hukum yang bisa dimintai pertanggungjawaban pidana itu. Frasa "setiap orang" dalam Pasal 2 dan Pasal 3 UU TPK mengunci subjek hukum hanya pada natural person, bukan badan hukum (legal person).

Pada bagian penjelasan UU itu juga tidak menyebut atau memperluas tafsir "korporasi", apakah termasuk partai politik. Terlebih apabila tafsir korporasi 
itu hanya dibatasi pada istilah "perusahaan" saja, sementara parpol bukan sebuah perusahaan. Hal yang sama juga terdapat dalam Peraturan Mahkamah Agung Nomor 13 Tahun 2016 tentang Tata Cara Penanganan Perkara Tindak Pidana oleh Korporasi. Definisi korporasi dalam PERMA itu mengacu pada Pasal 1 UU TPPK No 31Tahun 1999 bahwa "korporasi adalah kumpulan orang dan atau kekayaan yang terorganisasi baik merupakan badan hukum maupun bukan badan hukum”. Apakah tafsir korporasi dalam UU TPK dan PERMA bisa diperluas dengan memasukan parpol, sehingga parpol bisa dituntut pidana seperti ketika KPK menuntut korporasi PT Ninda Karya dalam kasus korupsi proyek pembangunan dermaga bongkar muat pada Kawasan Perdagangan Bebas dan Pelabuhan Bebas Sabang senilai Rp793 miliar, dan menyebabkan kerugian negara sebesar Rp313 miliar. Isu ini masih diperdebatkan hingga saat ini.

Dua pandangan bersebarangan, antara yang mendukung dan tidak. Aktivis ICW Donald Faris sebagaimana dimuat hukumonline.com (18/09/2018), ${ }^{12}$ mendukung jika parpol dituntut pidana tipikor dengan menyamakan parpol dan korporasi. Alasannya mengacu pada definisi korporasi dalam UU TPK dan PERMA sebagai "kumpulan orang dan atau kekayaan yang terorganisasi baik merupakan badan hukum maupun bukan badan hukum”. Bahwa sebagai badan hukum, parpol adalah "kumpulan orang dan atau kekayaan yang terorganisir..". Pendapat yang sama dari Peneliti Pusat Kajian Korporasi sekaligus pengajar Fakultas Hukum Universitas Pancasila, Armansyah, bahwa parpol bisa dipersamakan dengan korporasi dalam konteks tindak pidana korupsi. KPK, menurutnya, juga berwenang menetapkan parpol sebagai tersangka berdasarkan Pasal 20 UU No.31 Tahun 1999 tentang Pemberantasan Tindak Pidana Korupsi. Ia juga merujuk pada PERMA No. 13 Tahun 2016. ${ }^{13}$

Maria Silvya E. Wangga, dosen Universitas Trisakti dalam artikelnya di Jurnal INTEGRITO berjudul "Pertanggungjawaban Pidana Partai Politik sebagai Badan Hukum dalam Tindak Pidana Korupsi", ${ }^{14}$ yang diterbitkan KPK juga mendukung pendapat itu merujuk pada Pasal 4 PERMA No 13 Tahun 2016 dan Pasal 20 UU No. 31 Tahun 1999. Sedangkan yang tidak sependapat juga tidak sedikit, KPK termasuk didalamnya. Pimpinan KPK Saut Situomorang sebagaimana dimuat SINDO (5/09/2018) $)^{15}$ menyebut jika parpol dan korporasi berbeda. Saut menyebut korporasi memiliki tujuan dan maksud mencari keuntungan, sementara parpol tidak.

\footnotetext{
${ }^{12}$ https://www.hukumonline.com/berita/baca/lt5ba0c9cc5e3cf/mungkinkah-partai-politikdiperlakukan-sebagai-korporasi-dalam-kasus-tipikor , data akses 22 Maret 2019.

${ }^{13}$ Dalam hukumonline.com, ibid.

${ }^{14}$ https://jurnal.kpk.go.id/index.php/integritas/article/view/179/56, data akses 22 Maret 2019.

${ }^{15}$ https://nasional.sindonews.com/read/1335925/13/kpk-akui-parpol-dengan-organisasikorporasi-berbeda-1536144745, data akses 22 Maret 2019.
} 
Penulis berpendapat, meskpun legalitas pendiriannya sama-sama melalui Kemenkumham, namun secara "genetik", korporasi dan parpol memiliki perbedaan. Pertama, seperti yang disebut Saut bahwa korporasi memiliki tujuan dan maksud mencari keuntungan (laba), sementara parpol tidak. UU Parpol tidak menyebut salah satu tujuan dan fungsi parpol adalah untuk mencari keuntungan. Kedua, korporasi memiliki kepemilikan saham, apakah saham tunggal atau tidak, baik oleh individu (swasta/privat) maupun Negara (publik), sementara parpol tidak ada kepemilikan saham atau sebutan lain yang menandakan parpol dimiliki oleh satu-dua orang. Frasa "pendiri partai" tidak bisa disamakan dengan "kepemilikan partai". Ketiga, sumber keuangan korporasi murni dari kegiatan usaha, sementara parpol, bisa berasal dari APBN/APBD, iuran anggota, maupun sumbangan pihak ketiga.

Sehingga jika memakai perspektif KUHP, UU Tipikor dan PERMA Kejahatan Korporasi, tidak bisa atau sulit memasukan parpol sebagai entitas yang sama dengan korporasi, meskipun sama-sama sebagai badan hukum. Sama halnya dengan tidak bisa disamakan burung unta dengan burung lain, karena burung unta tidak bisa terbang, atau menyamakan elang yang pemakan daging dengan burung lain yang memakan biji-bijian, meskipun sama-sama disebut burung.

Bukan hal sulit untuk memahami alasan mengapa tidak dimasukannya parpol sebagai badan hukum yang bisa dituntut pidana. Undang-undang adalah produk politik DPR dan pemerintah, elit DPR tidak mungkin menjebak dirinya dengan memasukan parpol sebagai subjek hukum. Padahal dalam ajaran ilmu hukum, subjek hukum adalah orang dan badan hukum. Melepas tanggungjawab parpol atas kejahatan tipikor yang dilakukannya, bertentangan dengan dogma dan ajaran hukum.

Akan tetapi, perbedaan itu tidak lantas menutup ruang untuk memasukan parpol sebagai subjek hukum pidana tipikor. Perlu tafsir progresif dalam lapangan hukum pidana, apakah dengan merevisi KUHP, UU Tipikor, PERMA, UU TPPU, atau dengan memperluas subjek badan hukum dalam UU Tipikor, PERMA, UU TPPU untuk memasukan parpol sebagai subjek hukum pidana tipikor. Karena terbukti, korporasi bisa dijerat pidana tipikor seperti dalam kasus PT Duta Graha Indah (DGI) - yang saat ini bernama PT Nusa Konstruksi Enjiniring (NKE) diwakili pengurus korporasi Direktur Utama PT NKE Djoko Eko Suprastowo. PT DGI diduga melanggar Pasal 2 ayat (1) jo Pasal 18 Undang-Undang Nomor 31 Tahun 1999 sebagaimana telah diubah dengan Undang-Undang Nomor 20 Tahun 2001 tentang Pemberantasan Tindak Pidana Korupsi juncto Pasal 55 ayat (1) ke-1 dan Pasal 64 ayat (1) KUHP. Pada Kamis (3/01/2019) lalu, PT DGI (sekarang PT Nusa Konstruksi Enjiniring (NKE), divonis membayar denda Rp 700 juta Selain itu, PT DGI diminta membayar uang pengganti Rp 85 miliar. Duduk sebagai terdakwa sebagai perwakilan PT DGI adalah Direktur Utama PT NKE Djoko Eko 
Suprastowo. PT DGI juga dihukum pidana tambahan berupa mencabut hak untuk mengikuti lelang proyek pemerintah selama 6 bulan.

Hal yang sama diterapkan dalam tindak pidana lingkungan hidup dalam UU No. 32 Tahun 2009 tentang Perlindungan dan Pengelolaan Lingkungan Hidup (PPLH), melalui sanksi denda atau kerugian Negara menggunakan asas pertanggungajwaban mutlak (strict liability) ${ }^{16}$. Seperti vonis denda terhadap PT Kalista Alam pada 2014 lalu, yang dinyatakan secara sah dan meyakinkan bersalah melakukan perbuatan melawan hukum membakar lahan gambut tripa seluas 1.000 ha, dan dihukum ganti rugi sebesar Rp366 miliar. Pada 28 September 2016, PT Kallista Alam mengajukan Peninjauan Kembali (PK). Namun berdasarkan Putusan Kasasi Nomor 1 PK/Pdt/2017, pengadilan menolak permohonan Peninjauan Kembali yang diajukan PT. Kalista Alam. ${ }^{17}$ Kasus lain dapat ditemui dalam gugatan KLHK(Kementerian Lingkungan Hidup dan Kehutanan) terhadap PT National Sago Prima (NSP) di Riau, pada 2015. PT NSP sempat dimenangkan di Pengadila Tinggi (PT) Riau, sebelum kemudian MA melalui PK yang diajukan KLHK mengabulkan dan menghukum PT NSP dengan pidana denda satu triliun lebih. ${ }^{18}$

Memang disadari jika ajaran hukum pidana klasik selama ini hanya menyebut orang (manusia/naturalijke person) sebagai pemikul tunggal tanggungjawab pidana. Tanggungjawab pidana juga tidak bisa diwakilkan atau dialihkan (asas "siapa berbuat dia bertanggungjawab"). Penyertaan dalam pasal 55 KUHPidana adalah perluasan dari pertanggungjawaban pidana. Sementara dalam lapangan hukum perdata, subjek hukum lebih luas lagi, meliputi“orang” dan "badan hukum", sehingga badan hukum (legal person), sebagai suatu subjek hukum mandiri (persona standi in judicio), dapat melakukan perbuatan melawan hukum (onrechtmatig handelen) sehingga dapat dituntut pertanggungjawaban hukum (perdata). Kata awal dalam rumusan pasal pidana adalah "setiap orang" atau "barang siapa", yang merujuk pada natural person, bukan badan hukum (legal person).

Padahal, menurut Satjipto Rahardjo, badan hukum merupakan:

"Badan hasil ciptaan hukum yang terdiri dari corpus, yaitu struktur fisiknya dan kedalamnya unsur memasukkan unsur animus yang membuat badan mempunyai kepribadian. ${ }^{19}$ Oleh karena badan hukum itu merupakan ciptaan hukum, maka oleh penciptanya kematiannya ditentukan oleh hukum, undang-udang, atau peraturan lain".

\footnotetext{
${ }^{16}$ Pasal 88 UU PPLH

17 https://news.detik.com/berita/d-4257461/pembakar-hutan-kembali-dihukum-rp-366-mlsm-segera-eksekusi, data akses 22 Maret 2019.

${ }^{18} \mathrm{https} / / / \mathrm{www}$.benarnews.org/indonesian/berita/ma-pembakaran-hutan-01022019143640. html, 2 Januari 2019., data akses 22 Maret 2019.

${ }^{19}$ Hartanti. Tindak Pidana Korupsi. (Jakarta: Sinar Grafika, 2005).
} 
Jika memakai definisi ini, maka sebagai badan hukum, parpol memiliki struktur fisik, yang didalamnya memiliki unsur animus yang memiliki kepribadian. Parpol memiliki tujuan, sumberdaya; manusia dan prasarana, dan parpol bisa bertindak, atau melakukan perbuatan - perbuatan hukum, baik secara internal maupun secara eksternal, termasuk dapat melakukan tindakan perbuatan melawan hukum perdata dan pidana (Wederrechtelijk).

Pendapat Roscou Pound, seorang filosof besar hukum abad ke-20 dalam An Introduction to the Philosophy of Law (Pengantar Filosofi Hukum) dalam buku Romli Atmasasmita, seorang Pakar hukum pidana, berjudul "Asas-Asas Perbandingan Hukum Pidana" ${ }^{20}$, menguraikan bahwa berbicara tentang konsep "liability" atau "pertanggungjawaban", dilihat dari segi filsafat hukum, mengatakan bahwa "I... use the simple word "liability" for the situation whereby one exact legally and other is legally subjected to the exaction". Lebih lanjut, liability menurut Pound diartikan sebagai "suatu kewajiban untuk membayar pembalasan yang akan diterima pelaku dari seseorang yang telah "dirugikan" atas penderitaan yang dialami akibat perbuatan pelaku..

Merujuk pendapat Pound, maka parpol juga bisa dituntut tanggungjawab pidana jika terbukti kasus korupsi yang dilakukan kadernya merupakan "tindakan parpol itu sendiri". Akibat perbuatan (korupsi) itu maka rakyat dirugikan secara ekonomi. Korupsi sebagai "perbuatan pidana parpol secara institusi" maka penerapan sanksi pidananya juga bukan hukuman fisik sebagaimana diterapkan pada manusia (natural person). Teori dasar tindak pidana menyebutkan bahwa pertanggungjawaban pidana lahir dari tindak pidana, berdasar pada asas "kesalahan", tiada pidana tanpa kesalahan (Belanda: geen straf zonder schuld; actus non facit reum nisi mens sir rea), sebagai teori dasarnya. Parpol secara institusi telah melakukan perbuatan pidana yang dilarang oleh undang-undang (Tipkor).

Didalam KUHP memang tidak ditemukan pasal yang bisa menjerat badan hukum (legal person), selain natural person. Frasa "barang siapa" dalam KUHP hanya berlaku pada natural person, tidak untuk badan hukum (legal person). Pidana terhadap badan hukum korporasi hanya bisa ditemukan diluar KUHP, dalam beberapa peraturan perundang-undangan, selain UU Tipikor dan PERMA Kejahatan Korporasi. Seperti dalam UU No. 31 Tahun 2004 tentang Perikanan, UU No. 38 Tahun 2004 tentang Jalan, dan UU No. 32 Tahun 2009 tentang Perlindungan dan Pengelolaan Lingkungan Hidup, setelah sebelumnya, telah ada UU Darurat No. 7 Tahun 1955 tentang Pengusutan, Penuntutan dan Peradilan Tindak Pidana Ekonomi, yang juga bisa menjerat korporasi dalam

${ }^{20}$ Romli Atmasasmita,1989, Asas-Asas Perbandingan Hukum Pidana, cetakan pertama, Yayasan LBH, Jakarta. 
pertanggungjawaban pidana. Artinya, badan hukum, apapun bentuknya, bisa dijerat hukum, andai terbukti melakukan kejahatan pidana, termasuk parpol.

Asumsi selama ini yang mempersulit upaya menyeret parpol dalam kasus tipikor adalah bagaimana mengukur korupsi yang dilakukan elit parpol sebagai "tindakan parpol" ditengah alibi yang selama ini dihembuskan oleh elit parpol bahwa "tindakan/perbuatan pidana itu diwakili oleh pengurus partai", sehingga hanya pengurus partai sebagai natural person yang dapat diminta pertanggungjawaban pidana. Asumsi itu sebetulnya keliru. letak kekeliruannya pada cara berpikir yang "menempatkan tindakan (korupsi) pengurus, bukan sebagai tindakan parpol", meskipun tindakan itu disepakati bersama oleh beberapa pengurus parpol itu. Padahal, dalam beberapa kasus tipikor yang melibatkan elit partai, sebagaimana telah disinggung dimuka, ada pernyataan, pengakuan, dan benang merah yang mengarah ke pembiayaan politik partai. Artinya, itu adalah “tindakan secara institusi kepartaian'. Terlepas apakah keputusan itu dituangkan hitam diatas putih, atau disepakati secara lisan dan diam-diam.

Mendorong tuntutan tanggungjawab dan sanksi pidana terhadap parpol dalam kejahatan tipikor bisa dilakukan secara pidana dan administrasi. Secara pidana, revisi UU TPK dengan manambahkan frasa "badan hukum", selain frasa "setiap orang". Sehingga sebagai badan hukum, parpol bisa dijerat UU Tipikor apabila kasus korupsi yang diusut mengarah pada "aktifitas pembiayaan partai politik" seperti dalam kasus yang disebut diatas. Unsur kesengajaan (culpa) dan kesalahan bisa dibuktikan dengan perbuatan satu-dua orang atas nama institusi parpol tersebut secara melawan hukum sehingga Negara dirugikan. Penerapan sanksinya dengan menuntut penggantian kerugian Negara serta penerapan denda maksimal.

Sementara sanksi administrasi dengan cara menuntut pembekuan atau pembubaran parpol tersebut, seperti saat KPK menuntut penghapusan hak sipilpolitik (sipol) terdakwa tipikor yang dikabulkan oleh pengadilan. Kanalnya telah tersedia dalam UU Nomor 24 Tahun 2003 tentang Mahkamah Konstitusi sebagaimana telah diubah dengan UU Nomor 8 Tahun 2011. Salah satu kewenangan Mahkamah Konstitusi dalam UU MK adalah memutus pembubaran partai politik (parpol). Saat KPK berhasil membuktikan di pengadilan jika parpol terbukti melakukan kejahatan tipikor, maka putusan pengadilan akan menghukum parpol tersebut bersama pengurusnya. Putusan pengadilan tersebut kemudian dibawa ke Kemenkumham untuk pembekuan, dan MK untuk memutuskan parpol tersebut dibubarkan.

\section{Penutup}

Mendorong tanggungjawab dan sanksi pidana terhadap parpol yang terbukti melakukan kejahatan tipikor perlu didesak untuk memberikan shock 
theraphy sebagai ijtihad konsolidasi politik pasca reformasi hubungannya dengan cita pemberantasan korupsi. Saran yang bisa diusulkan adalah KPK bisa menggunakan UU Tipikor yang direvisi dengan menambahkan frasa "badan hukum" selain frasa "setiap orang" untuk mendakwa parpol ke meja hijau, disertai sanksi pengembalian kerugian Negara dan denda. Sanksi administrasi juga bisa diterapkan melalui pembekuan melalui Kemenkumham atau pembubaran parpol tersebut melalui jalur MK ketika dakwaan dan tuntutan KPK tersebut bisa dibuktikan. Meskipun hal ini akan mengalami hambatan besar terutama dari fraksi-fraksi parpol di DPR.

\section{Daftar Pustaka}

\section{Buku}

Atmasasmita, Romli 1989. Asas-Asas Perbandingan Hukum Pidana, cetakan pertama, Yayasan LBH, Jakarta.

Girling, John, 1997. "Corruption, Capitalism and Democracy", Routledge Studies in Social and Political Thought.

Hartanti. 2005. Tindak Pidana Korupsi. Sinar Grafika, Jakarta.

Lev, Daniel S, 1990. Hukum dan Politik di Indonesia, LP3ES, Jakarta.

Marzuki, Peter Mahmud, 2011, Penelitian Hukum, Kencana Prenada Media Group, Jakarta.

Roben Hoddes, "Introduction". Dalam Transparency International, 2004, "Global Corruption Report 2004", Special Focus: Political Corruption, Sterling VA: Pluto Press\&Transparency International, London.

\section{Jurnal}

Aris, Ismail, Irfan Amir, dan Septian Amrianto. 2019. "Konstitusionalitas Hak Angket Dewan Perwakilan Rakyat (Dpr) Terhadap Komisi Pemberantasan Korupsi (Kpk).” Al-Adalah: Jurnal Hukum dan Politik Islam 4 (2): 13558. https://doi.org/10.35673/ajmpi.v4i2.436.

Alkostar, Artidjo, Korelasi Korupsi Politik Dengan Hukum dan Pemerintahan di Negara Modern (Telaah tentang Praktik Korupsi Politik dan Penanggulangannya), JURNAL HUKUM No. Edisi Khusus Vol. 16 Oktober 2009: 155 - 179. https://jurnal.kpk.go.id/index.php/integritas/ article/view/179/56, data akses 22 Maret 2019.

\section{Internet}

Benarnews.org, Putus Bersalah Perusahaan Pembakar Hutan, MA diapresiasi, sumber : https://www.benarnews.org/indonesian/berita/ma-pembakaranhutan-01022019143640.html, 2 Januari 2019., data akses 22 Maret 2019

Detik.com, Pembakar Hutan Kembali dihukum Rp 366 M, LSM Segera Eksekusi, sumber :https://news.detik.com/berita/d-4257461/pembakar-hutan-kembali -dihukum-rp-366-m-lsm-segera-eksekusi, data akses 22 Maret 2019

Hukumonline.com, Mungkinkah Partai Politik Diperlakukan sebagai Korporasi dalam Kasus Tipikor, sumber :https://www.hukumonline.com/berita/baca/ 
1t5ba0c9cc5e3cf/mungkinkah-partai-politik-diperlakukan-sebagai-korporasi-dalam-kasus-tipikor, data akses 22 Maret 2019.

Idntimes.com, Daftar Lengkap 100 Kepala Daerah Ditangkap KPK, sumber https://www.idntimes.com/news/indonesia/lia-hutasoit/daftar-lengkap-100 -kepala-daerah-ditangkap-kpk-sejak/full data akses 23 Maret 2019 pukul 16.15 wita.

Kontan.co.id, Kasus yang Ditangani Berdimensi Politik, sumber :https://nasional.kontan.co.id/news/kpk-6117-kasus-yang-ditangani-berdimensi-politik data akses Kamis 22 Maret 2019.

KPK.go.id, Korupsi dan Demokrasi di Indonesia, sumber: https://www.kpk.go.id/id/publikasi/laporan-tahunan/79-berita/berita-media 13114-korupsi-dan-demokrasi-di-indonesia data akses 22 Maret 2019.

http://8iacc.org/ data akses 22 Maret 2019.

Sindonews.com, KPK Akui Parpol dengan Organisasi Korporasi Berbeda, sumber https://nasional.sindonews.com/read/1335925/13/kpk-akui-parpoldengan-organisasi-korporasi-berbeda-1536144745 data akses 22 Maret 2019.

\section{Undang-Undang}

Undang-Undang Nomor 31 Tahun 1999 sebagaimana telah diubah dengan Undang-Undang Nomor 20 Tahun 2001 tentang Perubahan UndangUndang No. 31 Tahun 1999 tentang Pemberantasan Tindak Pidana Korupsi ((Lembaran Negara Republik Indonesia Tahun 2001 Nomor 134, Tambahan Lembaran Negara Republik Indonesia Nomor 4150)

Undang-Undang Nomor 30 Tahun 2002 sebagaimana telah diubah dengan Undang-Undang No. 19 Tahun 2019 Tentang Perubahan Kedua Atas Undang-Undang No. 30 Tahun 2002 tentang Komisi Pemberantasan Tindak Pdana Korupsi (Lembaran Negara Republik Indonesia Tahun 2019 Nomor 197, Tambahan Lembaran Negara Republik Indonesia Nomor 6409)

Undang-Undang Nomor 24 Tahun 2003 sebagimana telah diubah dengan Undang-Undang Nomor 8 Tahun 2011 tentang Mahkamah Konstitusi (Lembaran Negara Republik Indonesia Tahun 2011 Nomor 70, Tambahan Lembaran Negara Republik Indonesia Nomor 5226)

Undang-Undang Nomor 32 Tahun 2009 tentang Perlindungan dan Pengelolaan Lingkungan Hidup (Lembaran Negara Republik Indonesia Tahun 2009 Nomor 140, Tambahan Lembaran Negara Republik Indonesia Nomor 5059) 